\title{
Internet Technology in the Economic Sector: Gojek Expansion in Southeast Asia
}

\author{
Rina Tridana ${ }^{1}$ \\ ${ }^{1}$ Universitas Indonesia \\ *Corresponding author. Email: rina.tridana98@gmail.com

\begin{abstract}
Current political and economic developments and even daily social life cannot be separated from the Internet. The Internet makes it possible to read the news, express our thoughts, shop, check the latest movies, or even book a flight or a hotel room. This is only a short list of the activities that can be done on the Internet with the help of a cell phone and various applications that are installed to increase the users' mobility.
\end{abstract}

Keywords: Internet, Economics, Southeast Asia, Gojek, Neoliberalism

\section{INTRODUCTION}

Current political and economic developments and even daily social life cannot be separated from the Internet. The Internet makes it possible to read the news, express our thoughts, shop, check the latest movies, or even book a flight or a hotel room. This is only a short list of the activities that can be done on the Internet with the help of a cell phone and various applications that increase the user's mobility. This paper will discuss how the internet-based economy helps our daily needs. In this case the focus is on ridehailing (also referred to as ridesharing) companies such as Gojek, one of the Indonesian unicorns (privately-owned startups valued at over $\$ 1$ billion USD).

\subsection{The Internet as an Economic Tool}

A combination of supportive government policies and political stability and transparency shaped Indonesia's political and economic development. Indonesia is currently experiencing economic growth. According to Chief of the Central Bureau of Statistics of Indonesia Suharyanto (Badan Pusat Statistik/BPS), in 2018 Indonesia's economic growth reached $5.17 \%$ an increase over five years ago ${ }^{1}$. In 2014, economic growth had reached $5.01 \%$, and then it dropped to

\footnotetext{
${ }^{1}$ Caesar Akbar, "Pertumbuhan Ekonomi 2018 Terbaik Sejak 2014", https://fokus.tempo.co/read/1172741/pertumbuhanekonomi-2018-terbaik-sejak-2014/full\&view=ok, $\quad(6$ Februari 2019). Accessed June, 302019.
}

$4.88 \%$ a year later. After that economic growth tended to increase from $5.03 \%$ to $5.07 \%$ in 2017 , and it has improved since then.

Even though Indonesian economic growth slowed in 2014 because of the impact of the 2008 economic recession, Indonesia's economic growth has surpassed other ASEAN countries. ${ }^{2}$ According to the International Monetary Fund's Report of October 2017, Indonesia's per capita income is fifth among ASEAN countries, with Singapore ranking first. The income data for the top 10 ASEAN countries are listed:

1. Singapore (US\$93,680)

2. Brunei Darussalam (US\$ 77,700)

3. Malaysia (US\$ 30,430)

4. Thailand (US\$18,730)

5. Indonesia (US\$ 13,120)

6. The Philippine (US\$ 8,780)

7. Laos (US\$ 7,910)

8. Vietnam (US\$7,380)

9. Myanmar (US\$ 6,850)

\footnotetext{
2 "Survei Ekonomi OECD Indonesia". (Maret 2015), https://www.oecd.org/economy/Overview-Indonesia2015-Bahasa.pdf. Accessed August 25, 2019.
} 


\section{Cambodia (US $\$ 4,300)^{3}$}

According to 2019 data from The Economist, among all ASEAN countries, Myanmar's economic growth has moved into the first position while Indonesia's is number six.

1. Myanmar $(7.1 \%)$

2. Vietnam $(6.9 \%)$

3. Laos $(6.8 \%)$

4. Cambodia $(6.5 \%)$

5. The Philippine (5.7\%)

6. Indonesia (5.2\%)

7. Malaysia (4.5\%)

8. Thailand $(3.5 \%)$

9. Singapore $(1.6 \%)$

\section{Brunei Darussalam $(0.5 \%)^{4}$}

Part of the support for economic growth comes from the creative economy. The creative economy is "An evolving concept based on creative assets potentially generating economic growth and development (UNCTAD, 2010)."

One of today's creative economies that uses the Internet is ride hailing. Ride hailing is a digital-based mass transportation business concept that uses the driver's personal vehicle (such as a car or a motorcycle). This means that a single trip in the driver's vehicle involves only the passenger who hailed the ride (maybe with their friends) and the driver. No other passengers are involved. The advantage of the ride hailing system is that the consumer can determine which route will be traveled to reach the destination. For example, if a passenger just got back from office and wanted to stop by the mini market, the driver can go directly there ${ }^{6}$.

${ }^{3}$ Dimas Novita Sari, "Pendapatan Per Kapita Indonesia Hanya Tempati Peringkat Kelima di Asia Tenggara," https://finansial.bisnis.com/read/20180107/9/723969/p endapatan-per-kapita-indonesia-hanya-tempatiperingkat-kelima-di-asia-tenggara, (07 Januari 2018). Accessed August, 24, 2019.

${ }^{4}$ Tommy Kurnia, "Melihat Pertumbuhan Eonomi di ASEAN, Indonesia Peringkat Berapa?" https://www.liputan6.com/bisnis/read/4020268/meliha t-pertumbuhan-ekonomi-di-asean-indonesiaperingkat-berapa, (24 Juli 2019). Accessed August 24, 2019.

5 "Apa itu Ekonomi Kreatif," http://indonesiakreatif.bekraf.go.id/ikpro/programs/ap a-itu-ekonomi-kreatif/. Accessed June, 30, 2019.

${ }^{6}$ Bramantia Tamtama, "Ride Sharing dan Ride Hailing di Indonesia, Apa bedanya?"
Before Gojek and Grab ever existed in Southeast Asia, Uber had expanded into the region with its private car ride hailing. Uber, as the first ride-hailing model, used to had it chance to expanded Southeast Asian market before finally leaving the region in March 2018. When Uber left, Grab acquired all its operations ${ }^{7}$. However, Uber still dominated the North American and European markets ${ }^{8}$.

Two ride-hailing giants, Gojek and Grab, have successfully expanded the Southeast Asia. In addition, there are also local ride-hailing (and ride sharing) companies across Southeast Asia. Brunei had one ride hailing service called Dart that has rolled out since $2017^{9}$. Dart service provides private cars and local taxies. ${ }^{10}$ The Philippine has six ride hailing companies such as Hype,${ }^{11}$ Ipara that started service in May 2018, Go Lag and Micab (Micab is actually ride sharing) that started service at the end of May 2018, and Hirna (local taxies and private cars), and e-pick me up (a company that used to be a logistics company that catered to the delivery of various goods in The Philippines and now provides local taxies, vans, carpools, and ride sharing). ${ }^{12}$

Transportation startup (Gojek) has been one of the most successful unicorns, and, with just one ap, it has changed how Indonesians fulfill their everyday needs. These needs include transportation (motorcycle/Gojek, car/Gocar), food delivery and sending goods (Gosend), paying bills, shopping or cleaning, massage, repairs, laundry, and many services. Gojek has currently expanded in the Southeast Asian countries of Singapore, Thailand, and Vietnam, but it had a problem when it tried to expand to The Philippines.

http://thegaspol.com/ride-sharing-dan-ride-hailling-diindonesia-apa-bedanya/ (21 Maret 2019). Accessed August, 242019.

${ }^{7}$ Pingit Aria, "Rugi Rp. 74,3 Triliun, Uber jadi beban Softbank",

https://katadata.co.id/berita/2019/08/09/rugi-rp-743triliun-uber-jadi-beban-softbank, (9 Agustus 2019). Accessed August, 24, 2019.

${ }^{8} \mathrm{Ibid}$.

${ }^{9}$ Aaron Wong, "Brunei's First Ride Hailing Mobile App Dart To Launch May 5", https://www.bizbrunei.com/2017/05/bruneis-first-ridehailing-mobile-app-dart-launch-may-5/ (May 4 2017). Accessed August 25, 2019.

10 https://www.dartbrunei.com/\#services-3-section. Accesed August 25, 2019

${ }^{11}$ Zafirah Salim, "5 Ride Hailing Startups Enter Philippines Despite Grab's Domination-4 To Start Services This May" (May, 9 2018). Accessed August 25, 2019.

12 https://www.epickmeup.com/about-us ...accessed August, 252019. 
Singapore has Ryde (private car services and document messenger services), MVL (Mass Vehicle Ledger), TADA, Filo technologies, Jugnoo (Indianbased ride hailing), Kardi, and Urge. ${ }^{13}$ Malaysia has three other ride hailing services aside from its super ap Grab. Dego (motorcycle taxi and goods delivery), MyCar, JomRides, MULA, Dacsee, and Riding Pink. In Thailand there is All Thai Taxi, Uber, and Easy Taxi. In Cambodia there is TADA, a Singapore ride hailing company.

Vietnam has Be that rolled out on December 17, 2018. Be provides car and motorbike taxies. It will also have food delivery, e-payment, and financial services in the future. ${ }^{14}$ Vietname also has a company called FastGo. Laos has Loca. ${ }^{15}$ Myanmar has Oway Ride, OK Taxi, Get Ride, and FastGo.

Economic trade over the Internet (Information Technology/IT) is regarded as a vital globalization and technological progress. The IT sector is and will be the fastest growing business in the world. For over a decade, the world's rapidly growing demand for social networks for business, for the Internet to receive news, for e-tools to transmit knowledge and more, has allowed more and more entrepreneurs to successfully find new ways to do business in the IT sector. There are e-shops, business platforms, and applications that help simplify daily operations and reduce the use of limited resources while increasing productivity. Therefore, the number of rapidly developing high-tech startup businesses is growing ${ }^{16}$. According to Graham and Spaulding (2005), ${ }^{17}$ the main factor that distinguishes a startup from other businesses is its rapid growth.

\footnotetext{
${ }^{13}$ Sammi Kor, "5 Taxi Apps in Singapore To Support and Bring Back The Price War promo Codes We All Miss", https://thesmartlocal.com/read/taxi-apps/ (Oct, 23 2018).

14 “Vietnam's Newest Ride-hailing App 'Be' Gets Funding Ahead of Launch" (December 13, 2018) https://www.reuters.com/article/us-bevietnam/vietnams-newest-ride-hailing-app-be-getsfunding-ahead-of-launch-idUSKBN1OCOTK Accessed August 26, 2019.

15“LOCA Core Value" https://www.loca.la/about.php. Accessed August 26, 2019.

${ }^{16}$ Živilè Tunčikienė; Gabrielè Sinkevičiūtè, "Strenthening Opportunities of Economic Relations Between Lithuania and Sweden Within the Perspective of IT Startup Company's Development," Business, Management and Education, 2017, 15(1).

${ }^{17}$ J. P. Graham and R. Spaulding. 2005.

Understanding Foreign Direct Investment

http://www.going-

global.com/articles/understanding_foreign_direct inve stment.html; ibid.
}

Startup business is "modeled" for rapid growth The mere fact that the business is newly established, does not mean that it is a startup. Startup business does not have to be based on high-tech or venture capital financing. The essence of this businessexplosive growth.

According to Nesta's empirical research that is responsible for the promotion of innovation in the UK, "the startup" is "a young, innovative, growth-oriented business, that is looking for a long-term sustainable business model" (Dee et al., 2015). ${ }^{18}$ A startup is an organization that is set up to look for a unique and measurable business model (Blank \& Dorf, 2012) ${ }^{19}$. Thus, the term startup includes a business based on innovative, advanced technologies combined with a sharp growth in the traditional business model elements. According to Ries $(2012)^{20}$, a startup is a newly established business, focusing on new products and services that are based on rapid high-tech development. Norris (2014) ${ }^{21}$ described the startup companies as newly established companies that have a unique business idea and principles of operation based on technology and/or innovation.

The Internet has a two-way effect on export behavior. First, the Internet may affect developed and developing countries differently. Internet penetration is positively correlated with exports from developing countries to developed countries but not to other developing countries. Second, it assesses the extent to which Internet use affects exports, taking into account the endogeneity of internet use. ${ }^{22}$

Capitalist society has been evolving from consumer-based, where having ownership was the main concern to a hyper-consumption society that places more emphasis on time, experience, and opportunity than on possession itself (Aquise, 2014). ${ }^{23}$

\footnotetext{
${ }^{18}$ N. D. Dee; D. Gill; C. Weinberg and S. McTavish, 2015. "Startup Support Programmes: What's the Difference?" Available in the Internet: http://www.nesta.org.uk/sites/default/files/whats the diff_wv.pdf ; ibid.

${ }^{19}$ S. Blank; B. Dorf, The Startup Owner's Manual:The Step-By-Step Guide for Building a Great Company, California: K\&S Ranch, 2012.

${ }^{20}$ E. Ries, LEAN Startup Metodika. Vilnius: Eugrimas, 2012.

${ }^{21}$ D. Norris, The 7-day startup: you don't learn until you launch. New York: Lioncrest Publishing, 2014.

${ }^{22}$ R.D. George, Scott Clarke and J. Wallsten, "Has The Internet Increased Trade Developed and Developing Country Evidence," Economic Inquiry, Jul. 2006, 44, 3.

${ }^{23}$ Xavier de Lecaros Aquise (2014), "The Rise of Collaborative Consumption and the Experience Economy," The Guardian, January.
} 
The term "sharing economy," coined by Lessig (Walsh, 2011), ${ }^{24}$ has become a new business platform that fundamentally changes the traditional business market (Cusumano, 2015). ${ }^{25}$

Belk $(2007)^{26}$ described the idea of sharing as the act and process of distributing what is ours to others for their use and/or for the process of receiving or taking something from others for our utilization. The sharing economy not only breaks down all industrial categories, but also maximizes the use of scarce resources (Allen, 2014). ${ }^{27}$ One of the characteristics of the sharing economy is to focus on access rather than ownership, where firms have been transformed into the facilitators of exchange rather than producers. ${ }^{28}$

Through user-centered strategies, the sharing economy has been applied to providing both tangible and intangible products and services, including accommodation, cars, space, money, knowledge, and skills. The sharing economy is an economic model based on sharing underutilized assets-from space to skills to stuff-for monetary or non-monetary benefit. It is largely focused on peer-to-peer (P2P) marketplaces" (Botsman, 2013). ${ }^{29}$ The key effective factors in the sharing economy include maximization of satisfaction and loyalty (Masoodul, 2013) ${ }^{30}$ for both sides, providers (i.e., supply) and users (i.e., demand) (Dick \& Basu, 1994). ${ }^{31}$

\footnotetext{
${ }^{24}$ Bryan Walsh (2011), "10 Ideas That Will Change the World: Today's Smart Choice: Don't Own. Share," TIME, March.

${ }^{25}$ Michael A. Cusumano, "Technology Strategy and Management: How Traditional Firms Must Compete in the Sharing Economy," Communications of the $A C M, 2015,58(1), 32-34$.

${ }^{26}$ Russell Belk, "Why Not Share Rather Than Own?" The Annuals of the American Academy of Political and Social Science, 2007, 611, 126-140.

${ }^{27}$ Darcy Allen; Chris Berg, "The Sharing Economy: How Over-Regulation Could Destroy an Economic Revolution," Institute of Public Affairs. 2014 ${ }^{28}$ Ibid.

${ }^{29}$.R Botsman, (2013). The Sharing Economy Lacks A Shared Definition.

http://www.fastcoexist.com/3022028/the-sharingeconomy-lacks-a-shared-definition. Accessed July 3, 2019.

${ }^{30}$ Hassan Masoodul et al., "Measuring Customer Satisfaction and Loyalty through Service Fairness, Service Quality and Price Fairness Perception: An Empirical Study of Pakistan Mobile Telecommunication Sector," Journal of the Science International (Lahore), 2013, 25(4), 971-980.

${ }^{31}$ A. S. Dick and K. Basu, "Customer Loyalty: Toward an Integrated Conceptual Framework," Journal of the Academy of Marketing Science, 1994, 22(2), 99103.
}

According to Forbes's 2013 data, the estimated growth of the sharing economy ${ }^{32}$ was at $25 \%$ with over $\$ 3.5$ billion in revenue. The basic concept of the sharing economy is to share people's needs or interests as well as to exchange fewer tangible assets such as time, space, skills, and money (Benkler, 2004). ${ }^{33}$ People use web platforms that bring together individuals who have underutilized assets with people who are willing to share the assets on a short-term basis (Cusumano, 2015). ${ }^{34}$

Furthermore, the Internet features that drive the sharing economy the most are the ubiquitous social networking and real-time technologies (Botsman, 2010). ${ }^{35}$ By using the social network system, all the processes between the provider and the consumer in the sharing business are convenient. It is easy to choose the service or product to be delivered at the right time and location (Gansky, 2010). ${ }^{36}$. Rinne et al. (2013) ${ }^{37}$ also mentioned that the P2P transaction model gives people a way to use the resources efficiently by matching supply and demand instantly. To safely establish the framework, it is also necessary to consider the various constraints of government, the legal system, and other social issues that regulate the sharing economy (Allen, 2014). ${ }^{38}$

\subsection{From Local to International}

Gojek is a local Indonesian ride-hailing business that was founded in 2010. This company did not venture outside of Indonesia until 2018, when Gojek decided to expand into several Southeast Asian countries (Thailand, The Philippines, Singapore, and Vietnam). Gojek received a US $\$ 500$ million

\footnotetext{
${ }^{32}$ Forbes, 2013 in Yoon C. Cho; and Kim, Bokyeong, "Investigating the Impact of Justice Dimension and Perceived Value on Customer Satisfaction for Sharing Economy of Accommodation", Journal of Business and Economics Research, Fourth Quarter, 2016, Vo. 14,4

${ }^{33}$ Yochai, Benkler, "Sharing Nicely: on Shareable Goods and the Emergence of Sharing as a Modality of Economic Production," Yale Law Journal, 2004, 114.

${ }^{34}$ Op.Cit.. Cusumano.

${ }^{35}$ R, Bostman (2010), "The Case for Collaborative Consumption," Video file retrieved from http://www.ted.com/talks/rachel_botsman_the_case_f or_collaborativeconsumption.html/, 2010.

${ }^{36}$ L. Gansky (2010), The Mesh: Why the Future of Business Is Sharing, New York: Penguin Group.

${ }^{37}$ April Rinne et al. (2013).Op.Cit in Yoon C. Cho; and Kim, Bokyeong, "Investigating The Impact Of Justice Dimension And Perceived Value On Customer Satisfaction For Sharing Economy Of Accommodation", Journal of Business and Economics Research, Fourth Quarter, 2016, Vo. 14, 4.

${ }^{38}$ Op.Cit..Allen.
} 
investment from several companies: Astra, Google, Tencent, Meituan, JD.com, and others. ${ }^{39}$ Gojek is a motorcycle/car ride-hailing business. Besides transportation, Gojek also delivers several other items, including food, documents, laundry, and so on.

Gojek launched its services in Thailand at the end of 2018 (Get). Also in November 2018, Gojek launched a trial of limited service for customers in Singapore, and on January 10, 2019, Gojek made the service available to everyone. Gojek's service has reached $80 \%$ of Bangkok. Aside from its car and twowheeler transportation service/ride hailing (Get-Win), Get also provides delivery and food delivery services (Get Delivery and Get Food). Gojek maximizes its business by creating local teams to run Get in such a way as to give on demand solutions in the region. ${ }^{40}$. Gojek has chosen to call its services "Get" in Thailand. This gives the business in each country the ability to determine not only their own destiny, but also their own identity.

In January 2019, The Philippines blocked Gojek's entry on concerns over foreign ownership. ${ }^{41}$ According to The Philippines' Minister of Transportation, the government had issued a moratorium on or termination of operational licenses for new on demand transportation services. According to Martin B. Delgra, chairman of the Land Transportation Franchising and Regulatory Board (LTFRB), Gojek's application was submitted on August 13, 2018, through the founding of Velox Technology Philippines, Inc. However, the "LTFRB Memorandum Circular (MC) 2018-016" was signed by the council on August 9, 2018.

According to the memorandum, the government was prohibited from accepting new registrations for Transport Network Vehicle Service operations. The moratorium was intended to allow The Philippine government to monitor the transportation services operating in its territory. This was because a lot of ride-hailing companies had obtained operational

39 Ervina Anggraini. (24 Mei 2018), "Investasi 'Kakap' Dorong Gojek Ekspansi di Asia Tenggara", https://www.cnnindonesia.com/teknologi/2018052411 2255-185-300897/investasi-kakap-dorong-gojekekspansi-di-asia-tenggara. Accessed July 7. 2019 40 "Gojek Launches Get in Bangkok" https://dailysocial.id/post/gojek-launches-get-inbangkok-thailand. Accessed August 27, 2019.

${ }^{41}$ The Philippine constitution limits foreign ownership to $40 \%$ for certain industry. (See 12 Januari 2019), "Temui Masalah Administrasi, Gojek Tetap Ngotot Ekspansi ke Filipina https://kumparan.com/@kumparanbisnis/temuimasalah-administrasi-go-jek-tetap-ngotot-ekspansi-kefilipina-1547291641862636415. Accessed July 7, 2019. permits from the government. ${ }^{42}$ Nevertheless, The head of Gojek's Public Policy and Government Relations said that Gojek is still in discussions with The Philippine government ${ }^{43}$. In addition, Gojek can still take another shot at The Philippine market by changing the affiliate's ownership structure.

There is ride-hailing competition in Singapore. After the departure of Uber in Southeast Asia, many ride-hailing service providers emerged in Singapore. Following local ride hailing start up, as well as Indiabased Jugnoo and Filo Technologies. ${ }^{44}$. Table 1 shows the ride-hailing companies who invested in Singapore.

Gojek is a different company from the company in Indonesia. Singapore is a unique and important market. It is highly developed and is made up of users who are very well acquainted with ride-hailing and have high standards. Gojek collaborated with Carousell, a service that offers ride-hailing perks (gocar/private car). Gojek also has partnerships with Singtel, Doctor Anywhere, GigaCover, Esso, and DBS Bank. Leveraging Gojek's large technology team in Singapore, Gojek also cooperates with KPMG and Singapore's Agency for Science, Technology, and Research (A*Star) on cybersecurity solutions. ${ }^{45}$

Within months of that investment, Gojek rolled into Vietnam, where it competes directly with Grab. Gojek's cautiously approach international growth has left it vulnerable to increasing scrutiny of the ridehailing industry by the region's regulators. In Vietnam, its Vietnamese unit is called Go-Viet, and it is more than $50 \%$ owned by local shareholders. ${ }^{46}$ As in Indonesia, Go-Viet offers motorbike ride-hailing and courier services in Hanoi and Ho Chi Minh City, the country's two largest metropolitan areas. Gojek's name derives from the Indonesian word for the country's ubiquitous motorbike taxis, ojek. While that has made it a powerful and easy to remember brand name in Indonesia, Nadiem Makarim, the founder of

42 "Moratorium Perizinan Transportasi On-Demand Baru Filipina Ganggu Ekspansi Gojek", https://dailysocial.id/post/moratorium-filipina-gangguekspansi-go-jek. Accessed August 27, 2019.

${ }^{43}$ Op. cit.

${ }^{44}$ Zafirah Salim, "New S'pore Ride Hailing App Filo To Launch Soon-Promises To Be Cheaper Than Taxis" (May 7, 2018), https://vulcanpost.com/639251/spore-ride-hailing-appfilo-technologies/. Accessed August 27, 2019.

${ }^{45}$ Lien Choong Luen, "Singapore Marathon Not a Sprint for Gojek" (May, 16 2019), https://www.businesstimes.com.sg/garage/singaporea-marathon-not-a-sprint-for-gojek. Accessed August 27, 2019.

${ }^{46}$ Kentaro Iwamoto; Shotaro, Tani, "Ride-Hailing Groups Grab and Go-Jek Wage Full on War in 2019", FT.com ; London (Jan 23, 2019). 
Gojek, thought it would not resonate in the Vietnamese market. Hence, Go-Viet was chosen. The drivers wear a red jacket emblazoned with a star that mirrors the national flag. ${ }^{47}$

According to Andre Soelistyo, Gojek is committed to bringing choices back to the ride-hailing market in the city state, the hub for innovation and urban mobility in Southeast Asia. In Vietnam, Gojek has linked up with Vietin Bank to offer e-payments. It has also announced a strategic partnership with Singapore's DBS Group Holdings, one of Southeast Asia's biggest lenders, with an eye toward launching a similar service there. ${ }^{48}$ Go-Viet has grabbed $35 \%$ of the market for two-wheeled ride-hailing in $\mathrm{Ho}$ Chi Minh City, following its soft launch there. The application has been downloaded 1.5 million times. Makarim admitted that interoperability is not yet available for Gojek and Go-Viet users. That must download two different apps to use the services in Indonesia and in Vietnam. This puts it at a disadvantage with Grab's single app, which can be used across borders.

Nguyen Vu Duc, Go-Viet's co-founder and chief executive, said the company plans to offer additional services that are currently available only in Indonesia. Car hailing, food delivery, and mobile wallet Go-Pay are at the top of the list. "It will provide Go-Shopping, on-site cleaners and beauticians in your home," $\mathrm{Mr}$ Nguyen said. "All of these will be rolled out in Vietnam based on market demand." Meanwhile Grab, currently available in 36 Vietnamese cities, has been facing regulatory hurdles to further expansion after assuming the operations of its rival Uber, which exited Southeast Asia in April. Uber's legacy in Vietnam still lingers, however, and some former Uber executives joined Go-Viet, including Mr Nguyen. Go-Viet is also attracting former Uber drivers and customers.

Gojek's arrival appears to be pushing Grab to improve its Vietnamese operations. The company is reportedly offering drivers better incentives and launched food delivery in May, the same month Gojek announced its US \$500 million expansion plans in Vietnam, Thailand, Singapore, and The Philippines. On September 11, just a day before Go-Viet's official full launch, Grab announced a "strategic partnership" with Hanoi-based digital payments service provider Moca "to expand mobile payments more rapidly across the country."

Makarim was a friend of Grab co-founder and chief executive Anthony Tan while they were at Harvard University in the United States. He said that

47 Erwida Maulia, "Go-Jek and Grab Race For Dominance in Southeast Asia", FT.com ; London (Sep 23, 2018).

${ }^{48}$ Op. cit. Kentaro et.al. while the fierce competition makes it hard to turn a profit in ride-hailing, it has a good side: spurring innovation. "If it wasn't for our competition, Gojek would not be as motivated to innovate and get this big," said Makarim. Gojek is reportedly making profits from its other services, but not from ridehailing.

Before the announcement of the Go-Viet partnership, Gojek claimed 105 million downloads of its app in Indonesia and had 1 million drivers operating in 144 cities and districts. Grab claims 8 million drivers and agents in 234 cities across Southeast Asia and 109 million downloads of its app. In response to the new competition, Grab said: "We have not seen our market share fall in Ho Chi Minh City since the start of August. In Vietnam, our business continues to grow tremendously. Transport is displaying strong month-on-month growth while our new verticals-food and parcel delivery, for example-are growing robustly. Grab welcomes competition." 49

\section{RESEARCH QUESTION}

Gojek has recently expanded into several Southeast Asian countries. A subject for further investigation is whether Gojek will expand further into other Southeast Asia countries and how it would accomplish the expansion.

\section{PURPOSE AND RESEARCH SIGNIFICANCE THEORY}

This paper will uses neoliberalism theory. The classical liberal view is the fear of the interference of government domination, and it attempts to free individuals from state oppression. Liberals believe in freedom, individual rights, and free markets. Liberalism emerged and developed as a reaction to important worldwide economic trends and events.

Michael Howard and John King draw on the work of Gerry Cohen and Michael Kalecki in order to develop a historical materialist account of the rise of neoliberalism. For Howard and King, social, political, and ideological factors are ultimately determined by the requirements of (advanced capitalist) production. However, contrary to the traditional Marxist presumption that technological developments are market-eradicating, Howard and King argue that the advent of post-Fordist methods of production, coupled with the expansion of the service sector and advances in Internet communications and technology and transportation, favored the development of smaller firms and thereby promoted rather than retarded the development of market relations. Therefore, it is in the facilitation of the efficient use of the productive power

\footnotetext{
${ }^{49}$ Op. cit Erwida.
} 
of such technological developments that the origin of neoliberalism is found.

Howard and King came close to acknowledging the causal impact of human agency. When they refer at times to technology as "a" rather than "the" determinant of socio-economic affairs, and admitting that "the causation was not, of course, all one way." When talking about the relationship between technology and social and political life, it is important that they should do so, not only for intellectual, but also for practical political purposes.

Picking up on a theme that was touched upon in Tsakolotos's contribution, it can be suggested that the rise of neoliberalism is the inevitable consequence of technological developments and global economic forces. Deterministic analyses, therefore, encourage a highly pessimistic view of the possibility of contesting and steering the direction of future policymaking. Indeed, such a deterministic analysis arguably underpins New Labour's commitment to market forces. The sociological analysis underpinning the Third Way also reduces politics to the task of seeking ways to passively adapt to the pre-ordained future produced by the inexorable forces of globalization, post-Fordism, and class dealignment, which forecloses the possibility of genuine debate over alternatives to the Anglo-Saxon model of capitalism.

Recognizing that the rise of neoliberalism was contingent on the agency of political actors provides a useful antidote to such determinism; thereby it is sensible to at least consider the possibility of challenging the current reliance on market forces (Finlayson, 2003). ${ }^{50}$

As maintained by Munck (2005), the possibility of a "self-regulating market" is a core assumption in classical liberalism. It is an important presumption among neoliberals as well. Efficient allocation of resources is the most important purpose of an economic system, and the most efficient way to allocate resources goes through the market mechanism. ${ }^{51}$ According to Hackworth (2007), "neoliberalism as it true form (ideology), rooted in the trilogy of the individual, the market and non state intervention. It advocates strong individual protections of property rights, rule of law, freely functioning

${ }^{50}$ A. Finlayson (2003). Making sense of New Labour. Lawrence and Wishart.

${ }^{51}$ Ronaldo Munck (2005), "Neoliberalism and Politics, and the Politics of Neoliberalism"; pp. 60-69 in Alfredo Saad-Filho and Deborah Johnston: Neoliberalism - A Critical Reader. London: Pluto Press. markets and fair trade." 52 Whenever technologies enter new industries, it substitutes workers who are performing routine tasks with capital. ${ }^{53}$ There are three main tactics that firms employ to empower themselves at the expense of workers: (1) legal (mis)classification; (2) regime shopping; and (3) employing the economically vulnerable.

\section{THEORITICAL OPERATIONALIZATION}

Workers in this kind of company (Gojek drivers, for example) are subject to the terms and conditions that the driver has consented to by using the company's software. However, the workers are not employees of the entity that signs their paychecks. In the case of drivers, they are asked to chase Gojek points as their incentive. Customers are expected evaluate the drivers' performance and to give them five-star points as a reward for good performance.

Gojek drivers do have some control over their working conditions. Anyone who has the tools is welcome to be a Gojek driver. These tools are a car/motorcycle, a valid ID, and a license plate. Drivers can choose when to start work, when to end their shifts, and when to take breaks. There is no direct oversight by a manager. The drivers log into their cellphones and wait patiently in their vehicles for a nearby customer's request to pick them up.

Gojek calls their drivers their partners, but in many ways, they are in fact Gojek employees. Gojek's quality control standards and software algorithms determine compensation and the conditions of employment.

\section{CONCLUSION}

Use of the Internet has dramatically changed both political and economic behavior. Use of internet applications has provided people access to a new kind of economy. One form of this lifestyle is the sharing economy, for example, ride-hailing services. Gojek is a ride-hailing platform that makes it easier for people organize their transportation and to fulfill everyday needs. Along with Grab, Gojek now is a competitor in Southeast Asia. Gojek managed to obtain enough investment funding to expand into several Southeast Asian countries.

52 J. Hackworth. (2007), The Neoliberal City, Ithaca, NY: Cornell University Press.

${ }^{53}$ Austin Zwick, "Welcome to the Gig Economy: Neoliberal Industrial Relations and the Case of Uber", GeoJournal Spatially Integrated Social Sciences and Humanities 2013, vol. 78. No. 4. 


\section{REFERENCES}

[1] 'Apa itu Ekonomi Kreatif'. Retrieved from http://indonesiakreatif.bekraf.go.id/ikpro/program s/apa-itu-ekonomi-kreatif/.

[2] 'Gojek launches get in Bangkok'. Retrieved from https://dailysocial.id/post/gojek-launches-get-inbangkok-thailand.

[3] 'LOCA core value'. Retrieved from https://www.loca.la/about.php.

[4] 'Moratorium perizinan transportasi on-demand Baru Filipina ganggu ekspansi Gojek'. Retrieved from https://dailysocial.id/post/moratoriumfilipina-ganggu-ekspansi-go-jek.

[5] 'Temui masalah administrasi', ['Gojek Tetap Ngotot Ekspansi ke Filipina']. Retrieved from https://kumparan.com/@kumparanbisnis/temuimasalah-administrasi-go-jek-tetap-ngototekspansi-ke-filipina-1547291641862636415 ..

[6] 'Vietnam's Newest Ride-hailing App 'Be' Gets Funding Ahead of Launch’ December 13, 2018. Retrieved from https://www.reuters.com/article/us-bevietnam/vietnams-newest-ride-hailing-app-begets-funding-ahead-of-launch-idUSKBN1OCOT.

[7] Akbar, C. 6 Februari 2019. 'Pertumbuhan Ekonomi 2018 terbaik sejak 2014'. Retrieved from

https://fokus.tempo.co/read/1172741/pertumbuha n-ekonomi-2018-terbaik-sejak

2014/full\&view=ok.

[8] Allen, D. and Berg, C. 2014 The sharing economy: how over-regulation could destroy an economic revolution. Institute of Public Affairs.

[9] Anggraini E 2018. Investasi 'Kakap' Dorong Gojek ekspansi di asia Tenggara. Retrieved from https://www.cnnindonesia.com/teknologi/201805 24112255-185-300897/investasi-kakap-doronggojek-ekspansi-di-asia-tenggara.

[10] Aria, P. 'Rugi Rp. 74,3 Triliun, Uber jadi beban Softbank. Retrieved from https://katadata.co.id/berita/2019/08/09/rugi-rp743-triliun-uber-jadi-beban-softbank, (9 2019 Agustus).

[11] Balaam David, N., Dilman and Bradford. 'Laissez-faire, laissez-passer : the liberal International political economy perspective' Introduction to international political economy $\left(6^{\text {th }}\right.$ ed $)$. Pearson, London 2014.

[12] Belk, R. (2007). 'Why not share rather than own?' The Annals of the American Academy of
Political and Social Science, 611(1), 126-140. https://doi.org/10.1177/0002716206298483.

[13] Benkler, Y. (2004). 'Sharing nicely: on shareable goods and the emergence of sharing as a modality of economic production'. Yale Law Journal, 114(2). https://doi.org/10.2307/4135731.

[14] Blank, S. and Dorf, B. 2012 The startup Owner's Manual:the step-by-step guide for building a great company. K\&S Ranch, CA.

[15] Botsman, R. 2010 "The Case for Collaborative Consumption," Video file retrieved from. Retrieved from http://www.ted.com/talks/rachel_botsman_the_ca se_for_collaborativeconsumption.html/, 2010.

[16] Botsman, R. 2013. 'The sharing economy lacks A shared definition'. Retrieved from http://www.fastcoexist.com/3022028/the-sharingeconomy-lacks-a-shared-definition.

[17] Cho, C. Y. and Bokyeong, K. 2016. 'Investigating the impact of justice dimension and perceived value on customer satisfaction for sharing economy of accommodation'. Journal of Business and Economics Research, Fourth Quarter, 14, p. 4.

[18] Clarke, G. R. G. and Wallsten, S. J. 2006. 'Has the internet increased trade? Developed and developing country evidence'. Economic Inquiry, 44(3), 465-484. https://doi.org/10.1093/ei/cbj026, ‘44,3

[19] Cusumano, Michael A, 2015. 'Technology strategy and management: how traditional firms must compete in the sharing economy'. Communications of the ACM, 58(1), 32-34.

[20] de Lecaros Aquise, X. 2014. 'The rise of Collaborative Consumption and the Experience Economy'. The Guardian, January.

[21] Dee, N. D., Gill, D., Weinberg, C. and McTavish, S. 2015. 'Startup Support Programmes: what's the difference ?' Available in the internet. Retrieved from http://www.nesta.org.uk/sites/default/files/whats the diff_wv.pdf.

[22] Dick, A. S. and Basu, K. (1994). 'Customer loyalty: Toward an integrated conceptual framework'. Journal of the Academy of Marketing Science, 22(2), pp. 99-113. https://doi.org/10.1177/0092070394222001.

[23] DiMaggio, P., Hargittai, E., Neuman, W. R. and Robinson, J. P. (2001). 'Social implication of the internet'. Annual Review of Sociology, 27(1), pp. 
307-336.

https://doi.org/10.1146/annurev.soc.27.1.307.

[24] Ekonomi, S. and organization for economic cooperation and development Indonesia. 2015. Retrieved from https://www.oecd.org/economy/OverviewIndonesia-2015-Bahasa.pdf.

[25] Finlayson, A. 2003 Making sense of New Labour. Lawrence and Wishart.

[26] Gansky, L. 2010 The mesh: why the future of business is sharing. Penguin Group, New York.

[27] Graham, J. P., R. and Spaulding 2005. 'Understanding foreign direct investment'. Retrieved from http://www.goingglobal.com/articles/understanding_foreign_direct _investment.html.

[28] Hackworth, J. (2007). 'The neoliberal'. City. Cornell University Press, Ithaca, NY.

[29] Harwit, E. (2004). 'Spreading telecommunications to developing areas in China: telephones, the internet and the digital divide'. China Quarterly, 180, 1010-1030. https://doi.org/10.1017/S0305741004000724.

[30] Hassan, M. Hassan, S., Nawaz, M.S. and Aksel, I. (2013). 'Measuring customer satisfaction and loyalty through service fairness, service quality and Price fairness perception: an empirical study of Pakistan Mobile Telecommunication Sector'. Science International (Lahore), 25(4), 971-980.

[31] Hrynyshyn, D. 2002 The political economy of the internet. York University, Toronto.

[32] Innis, H. 1951 The bias of communication. University of Toronto Press, Toronto.

[33] Iwamoto, K. and Tani, S. January 23, 2019. 'Ride-hailing groups grab and go-Jek wage full on War in 2019'. Retrieved from FT.com. London.

[34] Kor, S. 2018. '5 Taxi Apps in Singapore to Support and Bring Back the Price War promo Codes We All Miss'. Retrieved from https://thesmartlocal.com/read/taxi-apps/ (October, 23 2018).

[35] Kurnia, T. 24 Juli 2019. 'Melihat pertumbuhan Eonomi di ASEAN, Indonesia peringkat berapa ?' Retrieved from https://www.liputan6.com/bisnis/read/4020268/m elihat-pertumbuhan-ekonomi-di-asean-indonesiaperingkat-berapa.

[36] Lewis, P. A. On the Political Economy of NeoLiberalism: a Review of The Rise of The Market:
Critical Essays on the Political Economy of Neo-

Liberalism, King's College London doi: $10.1017 / \mathrm{S} 0266267106230979$

[37] Retrieved from https://www.dartbrunei.com/. '\#services-3-section'. $\quad$ Retrieved from http://opendefinition.org.

[38] Lin, J., Yu, Z., Wei, Y.D. and Wang, M. 2017. 'Internet Access, Spillover and Regional Development in China'. Sustainability. 9(6), 946.

[39] Luen, L. C. 'Singapore Marathon not a sprint for Gojek (May, 16 2019)'. Retrieved from https://www.businesstimes.com.sg/garage/singap ore-a-marathon-not-a-sprint-for-gojek ..accessed.

[40] Maail, G. Open data and the fight Against corruption in Indonesia, (February, 23 2017). Transparency International Reports, Berlin.

[41] Maulia, E. September 23, 2018. 'Go-Jek and grab race for dominance in Southeast Asia'. Retrieved from FT.com. London.

[42] Munck, R. 2005. "Neoliberalism and Politics, and the Politics of Neoliberalism"; hal', in Alfredo SAAD-filho and deborah Johnston: neoliberalism - a critical reader. Pluto Press, London (60-69).

[43] Norris, D. 2014 The 7 day startup: you don't learn until you launch. Lioncrest Publishing, New York.

[44] Owyang, J. (2013). 'The collaborative economy'. Altimeter Research.

[45] Ries, E. and Startup Metodika, L. 2012 Vilnius: Eugrimas.

[46] Salim, Z. 'New Spore Ride Hailing App Filo To Launch Soon-Promises To Be Cheaper Than Taxis" (May, 7 2018)'. Retrieved from https://vulcanpost.com/639251/spore-ridehailing-app-filo-technologies/.

[47] Salim, Z. 5 Ride hailing startups enter Philippines Despite grab's Domination-4 to start services this May (May 2018).

[48] Sari, D. N. 2018. 'Pendapatan per Kapita Indonesia hanya Tempati peringkat kelima di asia Tenggara'. Retrieved from https://finansial.bisnis.com/read/20180107/9/723 969/pendapatan-per-kapita-indonesia-hanyatempati-peringkat-kelima-di-asia-tenggara.

[49] Tamtama, B. 'Ride Sharing dan Ride Hailing di Indonesia, Apa bedanya ? Retrieved from http://thegaspol.com/ride-sharing-dan-ridehailling-di-indonesia-apa-bedanya/ (21 2019 Maret). 
[50] Terranova, T. (2000).'Free labor: producing culture for the digital economy'. Social Text, 63. Duke University Press 18, 2(Summer), p. 39.

[51] Thorsen, D. E. and Amund Lie, A. August 30 2019. 'What is neoliberalism?' Retrieved from https://pdfs.semanticscholar.org/0c89/731ee9a32 57a0baa9a4e302b578f1bbc59d2.pdf ..accessed.

[52] Tunčikienè, Ž. and Sinkevičiūtè, G. (2017). 'Strenthening opportunities of economic relations Between Lithuania and Sweden Within the perspective of IT Startup Company's development'. Business, Management and Education, 15(1), 57-76. https://doi.org/10.3846/bme.2017.357.
[53] Walsh, B. 201110 Ideas that will change the world: today's smart choice: don't own. Share. TIME, March.

[54] Wong, A. May 4 2017. 'Brunei's first ride hailing mobile App dart to launch May 5'. Retrieved from

https://www.bizbrunei.com/2017/05/bruneisfirst-ride-hailing-mobile-app-dart-launch-may-5/.

[55] Zwick, A. (2017). 'Welcome to the gig economy: neoliberal industrial relations and the Case of Uber'. Geojournal Spatially Integrated Social Sciences and Humanities, 83(4). 
Table 1. Ride-hauling companies investing in Singapore

\begin{tabular}{|c|c|c|c|c|c|c|}
\hline Player & $\mathrm{HQ}$ & $\begin{array}{c}\text { Singapore } \\
\text { Launch Date }\end{array}$ & Founded & Unique Feature & Fund Raised & Investor \\
\hline Jugnoo & India & May $1^{\text {st }}$ & 2014 & Price bidding system & US\$16 M & $\begin{array}{c}\text { Payt, Snow Leopard, } \\
\text { Tech Ventures }\end{array}$ \\
\hline Ryde & Singapore & May $2^{\text {nd }}$ & 2014 & Post-Trip tipping & US\$1.5 M & $\begin{array}{c}\text { Angel and Private } \\
\text { investor }\end{array}$ \\
\hline MVL & Singapore & July & 2018 & Zero commission & $\begin{array}{l}\text { Now raising } \\
\text { US\$16 M }\end{array}$ & Crowdfunding \\
\hline Go-jek & Indonesia & Few months & 2018 & $\begin{array}{l}\text { Wide range of on } \\
\text { demand services }\end{array}$ & US\$2.1 Bn & $\begin{array}{c}\text { Temasek, Tencent, } \\
\text { Sequoia Capital }\end{array}$ \\
\hline Dacsee & Malaysia & Q2 2019 & 2017 & Blockchain & US\$ $25 \mathrm{M}$ & $\begin{array}{c}\text { Private and } \\
\text { Institutional investor }\end{array}$ \\
\hline
\end{tabular}

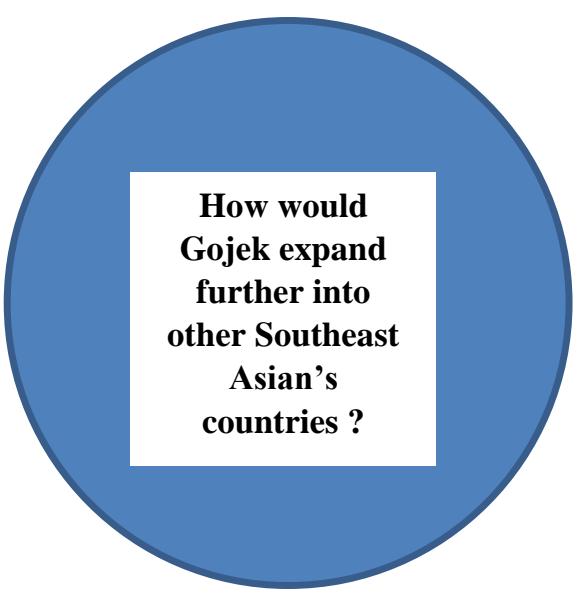

Figure 1 Research Significance

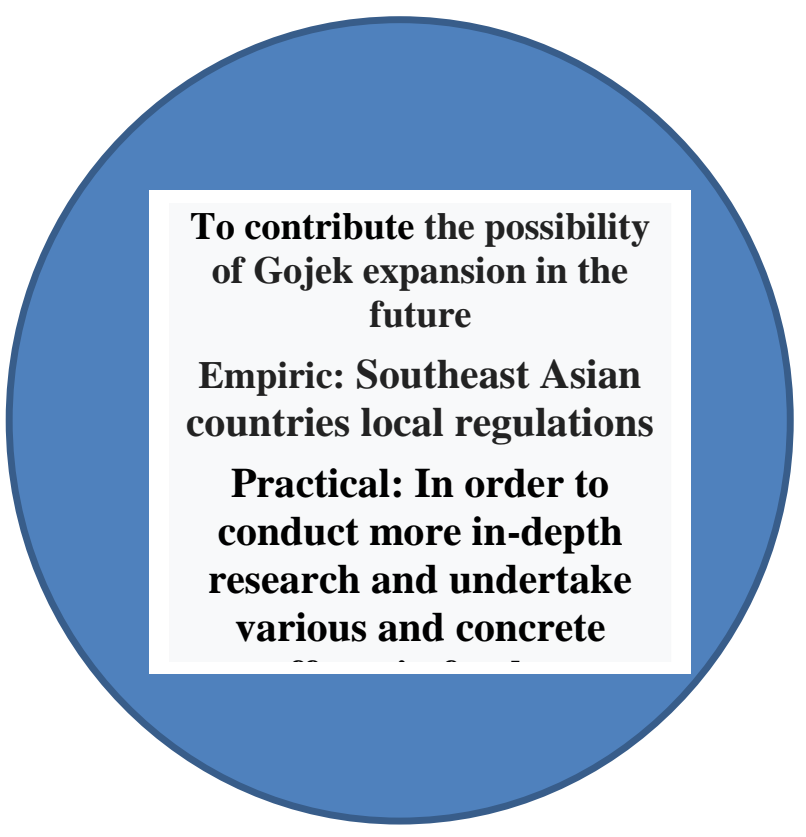

Figure 2 Research Purpose 